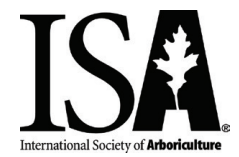

\title{
Tree Species as Tools for Biomonitoring and Phytoremediation in Urban Environments: A Review with Special Regard to Heavy Metals
}

\author{
Claudia Dadea, Alessio Russo, Massimo Tagliavini, Tanja Mimmo, \\ and Stefan Zerbe
}

\begin{abstract}
Trees play an important role for the improvement of environmental quality in urban areas. The improvement of microclimate, runoff mitigation, carbon storage and sequestration, noise reduction, air purification through removal and fixation of pollutants in leaves, stems, and roots are ecosystem services provided by urban greening. Additionally, the capacity of certain tree species as bioindicator or to take up contaminants has to be taken into account. Presented here is a review that focuses on 9 ornamental tree species commonly planted along urban streets in Central Europe. Their potential role for bioindication and phytoremediation was assessed. Due to physiological and morphological characteristics and to the intrinsic tolerance to several stress factors, some species seem particularly promising as an indicator for the state of the urban environment or to decrease the amount of specific pollutants. It must be pointed out that intrinsic species properties (e.g., tolerance and/or bioindication capacity for a specific contaminant) can help planners create an effective monitoring net in strategic areas of a city or to detect single contaminants representative of a specific human impact. In particular, Betula pendula and Robinia pseudoacacia can be considered ideal, low-cost candidates for phytoremediation. Due to their high hardiness, pollution tolerance, and their characteristic as pioneer species, both species might additionally be taken into account as biomonitors, or for their foliar trapping capacity. Tilia cordata is also suitable for phytoremediation in urban environments due to its foliar trapping capacity that can provide valuable information on airborne pollutants.

Key Words. Betula pendula; Bioindicators; Monitoring; Phytoremediation; Robinia pseudoacacia; Traffic Emission; Urban Planning; Volatile Organic Compounds.
\end{abstract}

Urban greening can potentially provide various ecosystem services, like microclimate improvement, runoff mitigation, carbon storage and sequestration, and noise reduction, as well as air purification through removal and fixation of pollutants in leaves, stems, and roots (Yang et al. 2005; Nowak et al. 2006; Buccolieri et al. 2011; Dobbs et al. 2011; Escobedo et al. 2011; Roy et al. 2012; Gómez-Baggethun and Barton 2013; Konijnendijk et al. 2013, Russo et al. 2014; Russo et al. 2016). In particular, trees can reduce air pollutants, both directly, by absorbing gaseous compounds, such as $\mathrm{SO}_{x}, \mathrm{NO}_{x}$, and $\mathrm{O}_{3}$ through leaf stomata, as well as indirectly, by decreasing air temperature and lowering the activity of chemical reactions, which produce secondary air pollutants in urban areas (Yang et al. 2005; Georgi and Dimitriou 2010).
Furthermore, leaves, bark, and the root system of trees, which are continuously exposed to atmospheric pollutants, such as wet and dry deposition, can trap or uptake, as passive accumulators, contaminants bound both to airborne particulate matter and/or to the soil, therefore becoming suitable for a long-term monitoring (Kardel et al. 2011).

Vehicle traffic mainly contributes to air pollution in urban areas, generating gaseous pollutants, such as nitrogen oxides $\left(\mathrm{NO}_{\mathrm{x}}\right)$, carbon monoxide $(\mathrm{CO})$, methane $\left(\mathrm{CH}_{4}\right)$, non-methane volatile organic compounds (NMVOCs), sulfur dioxide $\left(\mathrm{SO}_{2}\right)$, ammonia $\left(\mathrm{NH}_{3}\right)$, and particulate matter (Bell et al. 2011). Particulate matter contains organic compounds, hydrocarbons, acid aerosols, and metals attached or adsorbed to a carbonaceous core (de Kok et al. 2006; Bell et al. 
2011). Key pollutants are the so-called trafficrelated elements (TREs)-i.e. $\mathrm{Cd}, \mathrm{Mn}, \mathrm{Cu}, \mathrm{Mo}$, $\mathrm{As}, \mathrm{Sb}, \mathrm{Zn}$, together with $\mathrm{Pd}, \mathrm{Pt}$, and $\mathrm{Rh}$, which are regarded as emerging contaminants (Duong and Lee 2011; Fujiwara et al. 2011). Table 1 summarizes the main inorganic marker elements associated with various emission sources or processes (Duong and Lee 2011; Fujiwara et al. 2011; Calvo et al. 2013). TREs can precipitate directly on ground surfaces, or first accumulate in the atmosphere and then deposit on ground surfaces through rainwater transport (Gunawardena et al. 2013). For this reason, the presence of TREs not only in airborne particulate matter, but also in road dust, soils, vegetation, river sediments, and other related matrices, represent a risk factor for human health (Fujiwara et al. 2011 and references therein; Sawidis et al. 2011). The importance of this phenomenon needs to be viewed against the background of a general growth of large cities throughout the world and coupled with increasing vehicular traffic (Amato et al. 2009; Gunawardena et al. 2013).

In such complex environments like urbanindustrial areas, it is essential to identify plant species that can be used to assess the status and trends related to human health (Burger 2006) and are also potentially suitable for environmental quality improvement. Bioindication and phytoremediation are applied aspects of the uptake of chemical elements from soil to plants. According to Markert (2008) and Pellegrini et al. (2014), a bioindicator is an organism that contains information on the quality of the environment. In urban and industrial areas, vascular plants have been studied as bioindicators and bioaccumulators of trace elements. Evergreen species were used as a passive sampler and as indicators for airborne trace element in anthropogenic and remote sites. Also, the foliage of common deciduous trees was used for long-term monitoring of trace metal concentrations (Pellegrini et al. 2014 and references therein).

Phytoremediation has emerged as a potential tool to rehabilitate contaminated lands by removing pollutants from the environment or rendering them harmless (Pulford and Watson 2003). It is a "soft" remediation treatment that makes use of the ability of some plant species to accumulate certain elements, including TREs, in amounts exceeding the nutrient requirements of plants (Baker et al. 2000; Gupta et al. 2000). Ornamental tree and shrub species can also provide this ecosystem service in urban-industrial environments. Accordingly, urban planners could prioritize their potential in environmental quality improvement and maintenance, together with their stress tolerance, when selecting trees for urban-industrial areas or heavy-traffic roads. This strategy needs species-specific information, including their bioindication and phytoremediation potential, their biological characteristics, and any potential ecosystem disservices (Pataki et al. 2008; Lyytimäki and Sipilä 2009; Lyytimäki 2014); the latter, for example, might include the reduction of air flow by street trees (Vos et al. 2013; Nowak et al. 2014) or the production of pollen and its interaction with air pollutants (Traidl-Hoffmann et al. 2003).

Therefore, researchers carried out a literature review by focusing on the following information:

1) The general potential of trees for bioindication and phytoremediation in urban environments;

2) the tolerance of selected urban tree species against stress (as a continuous negative impact by biotic or abiotic factors on the plant, which causes damage and/or loss of productivity); and

3) recommendations for urban planners with regard to urban forestry.

The general bioindication and/or phytoremediation potential with regard to heavy metals are outlined first. Secondly, the review focuses on nine tree species that are commonly planted along streets in cities of central Europe, and provide comprehensive information on their role and potential for bioindication and phytoremediation. With this review, researchers provide a comprehensive basis for urban planning and urban forest management, also with regard to the potential role of those tree species in environmental quality improvement.

\section{Phytoremediation with Regard to Heavy Metals: Strategies and Application}

The dramatic increase of land surfaces and soils affected by pollution, salinization, and nonsustainable land use (Daily 1995) has led to the study and implementation of various technologies for cleaning contaminated sites. However, conven- 


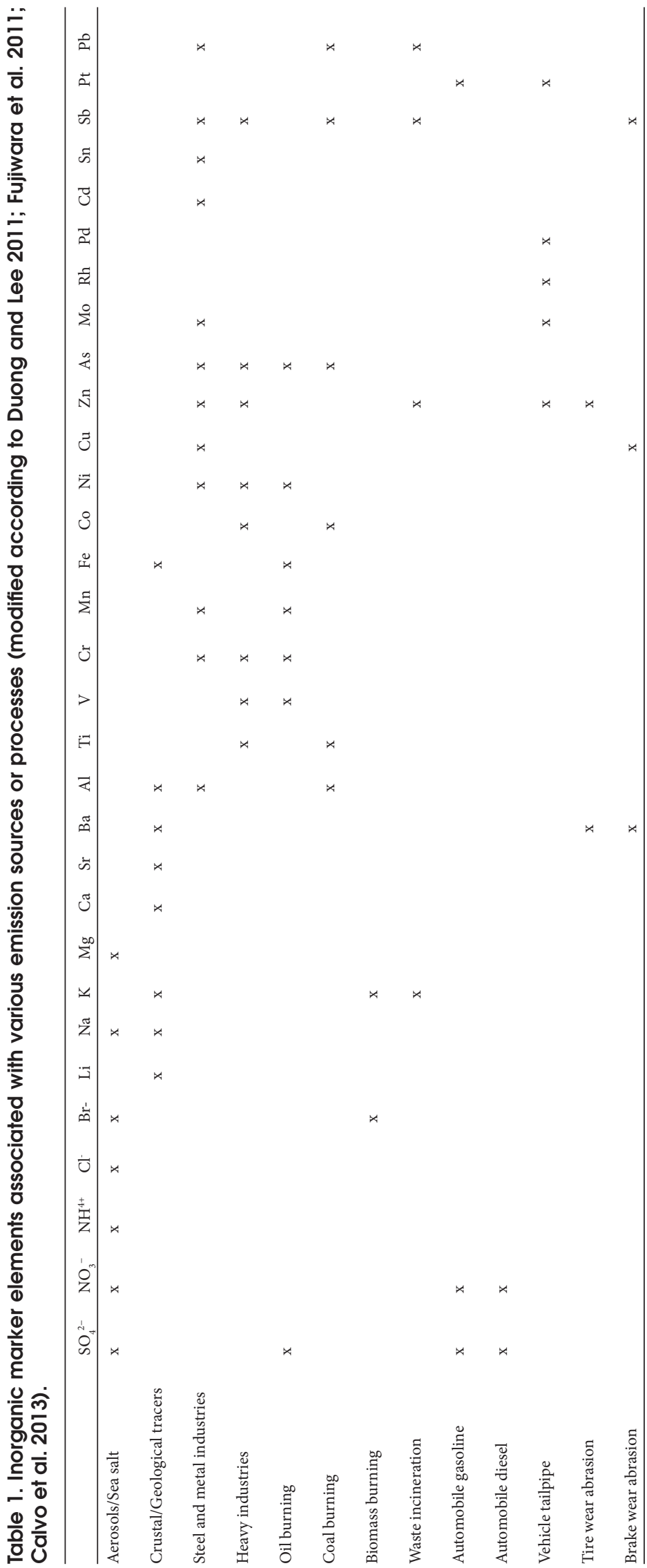

tional technologies, such as isolation and containment, mechanical/pyrometallurgical separation, or chemical treatment (Mulligan et al. 2001) are usually expensive, labor intensive, and soil disturbing (Gardea-Torresdey et al. 2005). Therefore, phytoremediation as plant-mediated decontamination/ detoxification processes has emerged as a methodology to remove, reduce, degrade, or immobilize environmental pollutants from air, soil, and water, thus restoring contaminated sites toward a clean, non-toxic environment (Pulford and Watson 2003; Pilon-Smits and Freeman 2006; Rajkumar et al. 2012 and references therein). The following specific techniques are considered for the phytoremediation of polluted sites, in particular concerning heavy metals:

a) phytoextraction-i.e., metal-accumulating plants (hyperaccumulator) remove metals from soil by concentrating them in harvestable parts of the plant. After a certain period of growth, the plants are harvested and disposed or incinerated (Raskin et al. 1997; Salt et al. 1998); and

b) phytostabilization-i.e., metaltolerant plants immobilize and inactivate metals through in situ rhizospheric processes, thus preventing the risk of further environmental degradation by leaching into groundwater or by airborne spread. Metals are thereby precipitated or sequestered by complexation and sorption mechanisms within the soils. Metal availability to plants is minimized and metal leaching into groundwater is reduced (Salt et al. 1995).

Since Bauman (1885), the capacity of plants to take up trace elements has been well-known. Areas with deposits of minerals often support a characteristic flora, rich in endemic species (e.g., Viola calaminaria Lej.) that through constitutive or adaptive mechanisms are able to tolerate or accumulate high metal concentrations in their tissues (Sheroan 2009; Monaci et al. 2011). Based on field surveys in nickeliferous soils (related to ultrabasic rocks), Brooks 
et al. (1977) defined those plants as "hyperaccumulators," which contain more than $1 \mathrm{mg}$ $\mathrm{Ni} \mathrm{g}^{-1}$ dry weight (Rascio and Navari-Izzo 2011). Accumulators are able to quickly translocate trace elements with a concentration of 100-1,000 fold higher than those found in non-accumulator species to the shoots and to the leaves, in particular, to the shoots and leaves (Baker 1981; Salt et al. 1998).

Consequently, effective phytoremediation depends on the plant's ability 1) to grow fast in nutrient-poor soils, 2) to develop a dense and/or deep root system, and 3) to show metal-tolerance traits (Baker et al. 1994; Brooks et al. 1994; Rascio and Navari-Izzo 2011; Sarma 2011). Furthermore, accumulators are genetically adapted and often strictly bound to their natural habitats and selective for specific metals. Urban trees, in particular, are considered efficient in pollutant removal thanks to their root systems, their large total leaf area, and their high transpiration (Pulford and Watson 2003; Rosselli et al. 2003; Meers et al. 2007; Unterbrunner et al. 2007; Brunner et al. 2008; Domínguez et al. 2008; Papa et al. 2012; Ugolini et al. 2013). Experiments have shown that tolerance against heavy metals can be induced by gradual acclimatization to metal stress (Dickinson et al. 1991; Turner and Dickinson 1993; Punshon and Dickinson 1997; Dickinson et al. 2002; Pulford and Watson 2003). Trees have the potential to enhance the remediation of brownfields, landfills, and other contaminated sites by absorbing, transforming, and accumulating a number of contaminants (Nowak and Dwyer 2007).

\section{REVIEW METHODOLOGY}

This review focuses on trees in urban areas, considering their capacity to withstand stress by heavy metals. Species-specific information on the phytoremediation potential and/or phytoremediation techniques will be identified. In particular, researchers consider the suitability for bioindication and heavy-metal stress tolerance and hardiness for a selection of tree species. Additionally to the specific phytore- mediation suitability of species, information was compiled with regard to their origin and morphological characteristics (e.g., maximum height, root development, or life span). Ecosystem services related to environmental quality improvement as well as potential disservices were assessed with special regard to volatile organic compounds (VOCs) and ozone emission.

In total, more than 134 literature sources, including books and manuals on dendrology, tree identification, and tree biology, as well as scientific papers, were reviewed, all extracted from the Scopus ${ }^{\circledast}$ and ScienceDirect ${ }^{\circledR}$ citation/ journal databases. For the current study, key words searched included "heavy metals" and the respective species name, as well as "urban areas" and/or "cities" together with "heavy metals." Figure 1 quantifies the revised literature sources differentiated into research topics.

The selected species were Acer pseudoplatanus L., Ailanthus altissima P. Mill., Betula pendula Roth, Carpinus betulus L., Ginkgo biloba L., Platanus $\times$ hispanica Mill. Ex Muenchh. "Acerifolia", Quercus robur L., Robinia pseudoacacia L., and Tilia cordata Miller (for biological and phytogeographical characteristics, see Table 2).

These species are frequently found in several medium-large cities in northern and northeastern Italy (Paludan-Müller et al. 2002; Comune di Padova 2006; Paoletti 2009; Comune di Bolzano, 2010; Semenzato et al. 2011; Comune di Merano 2012; Città di Torino 2013; Marziliano et al. 2013). Moreover, they are commonly planted in urban areas and along streets and highways throughout central and northwestern European cities (Pauleit et al. 2002; Pauleit et al. 2005; Sæbø et al. 2012; Sajdak and Velazquez-Marti 2012). Betula pendula, for example, occurs up to arctic (Sjöman et al. 2012) and near-arctic regions of Europe (Rosenvald et al. 2011; McBride and Douhonikoff 2012). Researchers did not consider trees with invasive root systems that are not suitable for streets, such as Populus and Salix species (Trees for Cities 2014). Some species listed in Table 2 (e.g., Robinia pseudoacacia and Betula pendula), while not specifically indicated for phytoremediation purposes, are considered 


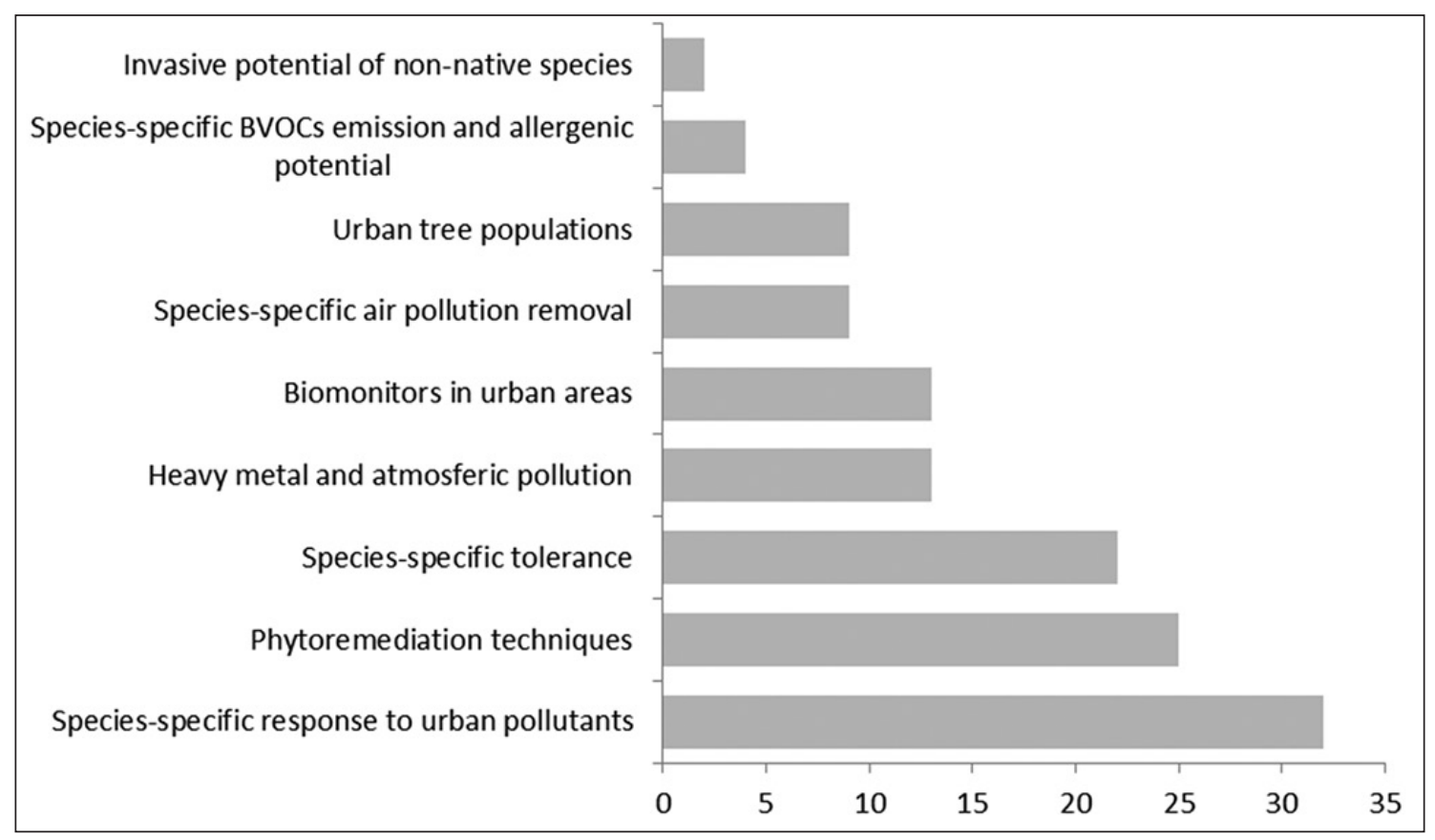

Figure 1. Research papers out of a total 134 reviewed papers with different aspects on phytoremediation in the urban environment.

Table 2. Biological and phytogeographical characteristics of the selected tree species (1-6 literature sources; life span refers to urban areas). Asterisk $\left(^{*}\right)$ indicates hybrid.

\begin{tabular}{|c|c|c|c|c|c|c|c|}
\hline Species & Family & $\begin{array}{l}\text { Indigenous (I); } \\
\text { non-native }(\mathrm{N})\end{array}$ & Native range & $\begin{array}{l}\text { Maximum } \\
\text { height }(\mathrm{m})\end{array}$ & $\begin{array}{l}\text { Average growth } \\
\text { rate per year }(\mathrm{cm})\end{array}$ & Root system & $\begin{array}{l}\text { Life span } \\
\text { (years) }\end{array}$ \\
\hline Acer pseudoplatanus L. & Aceraceae & $\mathrm{I}$ & $\begin{array}{l}\text { Europe and Caucasus/ } \\
\text { Asia }\end{array}$ & $15-30^{z}$ & $0.63^{y}$ & Fasciculate shallow ${ }^{x}$ & $40-70^{w}$ \\
\hline Ailanthus altissima P. Mill. & Simaroubaceae & $\mathrm{N}$ & China-North Vietnam & $20-30^{z}$ & $0.63^{y}$ & Taproots ${ }^{v}$ & $30-50^{\mathrm{v}}$ \\
\hline Betula pendula Roth & Betulaceae & I & Northern Europe & $30^{z}$ & $0.77^{y}$ & Fasciculate shallow ${ }^{\mathrm{x}}$ & 80 \\
\hline Carpinus betulus L. & Betulaceae & I & $\begin{array}{l}\text { Central and eastern } \\
\text { Europe }\end{array}$ & $20^{\mathrm{z}}$ & $0.71^{\mathrm{u}}-0.77^{\mathrm{y}}$ & Fasciculate deep ${ }^{\mathrm{x}}$ & $50-70^{w}$ \\
\hline Gingko biloba L. & Gingkoaceae & $\mathrm{N}$ & China, Japan & $20-30^{z}$ & $0.80^{\mathrm{y}}$ & Fasciculate deep ${ }^{\mathrm{x}}$ & $>250$ \\
\hline Platanus $\times$ hispanica Mill. & Platanaceae & $\mathrm{N}^{*}$ & Europe & $30^{z}$ & $0.89^{\mathrm{Y}}$ & Fasciculate deep ${ }^{x}$ & $100-120^{w}$ \\
\hline Quercus robur $\mathrm{L}$. & Fagaceae & I & $\begin{array}{l}\text { Central and northern } \\
\text { Europe }\end{array}$ & $30-40^{z}$ & $0.70^{\mathrm{u}}-0.77^{\mathrm{y}}$ & Taproots $^{\mathrm{x}}$ & $80-100^{w}$ \\
\hline Robinia pseudoacacia L. & Fabaceae & $\mathrm{N}$ & $\begin{array}{l}\text { Northeastern United } \\
\text { States }\end{array}$ & $20-25^{z}$ & $0.65^{\mathrm{u}}-0.74^{\mathrm{y}}$ & Fasciculate deep ${ }^{x}$ & $40-50^{w}$ \\
\hline Tilia cordata Miller & Tiliaceae & I & $\begin{array}{l}\text { England/Wales, central } \\
\text { and western Europe }\end{array}$ & $25^{\mathrm{z}}$ & $0.61^{\mathrm{u}}-0.62^{\mathrm{y}}$ & Fasciculate deep ${ }^{\mathrm{x}}$ & $80-100^{w}$ \\
\hline
\end{tabular}

${ }^{\mathrm{z}}$ von Malek and Wawrik (1985)

${ }^{x}$ Strobach et al. (2012)

x Odone (1992)

w Ferrari and Medici (1998)

v Russo et al. (2014)

u USDA (2012)

heavy-metals accumulators and potential biomarkers for the urban environment (Baycu et al. 2006; Tomašević et al. 2011). As an invasive species in Europe, Ailanthus altissima was also selected because it has become popular as a roadside tree in many European cities (Carinanos and Casares-Porcel 2011). In addition, experimental data show the tolerance of $A$. altissima to multiple heavy metals and suggest that this species can be tested for reforestation or phytoremediation of areas polluted with heavy metals (Gatti 2008). 


\section{RESULTS AND DISCUSSION}

Fast-growing tree species, such as Betula pendula and Robinia pseudoacacia, can be considered ideal low-cost candidates for phytoremediation applications, due to their high transpiration rates, fast growth rate after transplanting, and high biomass production. Moreover, Betula pendula has a high potential for phytoremediation, as it is able to mobilize trace elements in the soil and concentrate them at the root level, thus minimizing their translocation to leaves, wood, and bark (Evangelou et al. 2012). This has been shown, for example, for aluminum by Baker et al. (1981), and Rosselli et al. (2003). As Table 3 shows, all selected tree species are characterized by promising tolerance traits and show a high hardiness that render them suitable for a wide range of urban environments. Several studies have revealed that salt-tolerant plants may also tolerate other stresses, including heavy metals and xenobiotics, offering greater potential for phytoremediation research (Manousaki and Kalogerakis 2011). Additionally, the high tolerance to pests and diseases defines the ability of some deciduous trees for phytoremediation (Peuke and Rennenberg 2005; Lohmus et al. 2007; Rosenvald et al. 2011).

The potential/suitability for each species for phytoremediation and biomonitoring is shown in Table 4. Consequently, some of those species may provide information on the quality and quantity of trace elements. Betula pendula or Robinia pseudoacacia appear suitable for several applications related to phytoremediation. Furthermore, Betula pendula can grow on older heavy-metal soils by utilizing ectomycorrhizal fungi (Bothe 2011). Tilia cordata might be also suitable for phytoremediation due to its foliar trapping capacity and it can provide valuable information on airborne pollutants (Anicic et al. 2011; Tomaševic et al. 2011). There is a lack of information about the capacity of Carpinus betulus on heavy metals removal. Table 4 also shows the foliar trapping capacity of the tree species. In general, leaves with hairy, resinous, scaly, and coarse surfaces have the highest potential to intercept contaminants and particulate matter in comparison to smooth leaves (Beckett et al. 1998; Beckett et al. 2000; Yang et al. 2005).

Table 5 shows the allergenicity potential and the VOCs emission capacity of the selected urban tree species. Trees with high BVOC (biogenic volatile organic compounds) and pollen emissions should be avoided in urban areas. The air pollution due to BVOC emissions is related to their reactivity with some of the compounds released from anthropogenic sources, especially nitrogen oxides $\left(\mathrm{NO}_{\mathrm{x}}\right)$. Ozone, peroxyacyl nitrates, aldehydes and ketones, hydrogen peroxide, secondary

Table 3. Tree species' main tolerance traits; $h=$ highly suitable with regard to stress, $\mathrm{m}=$ moderately, $\mathrm{I}=\mathrm{low}$.

\begin{tabular}{|c|c|c|c|c|}
\hline Species & $\begin{array}{l}\text { Pollution } \\
\text { resistance }\end{array}$ & $\begin{array}{l}\text { Salt stress } \\
\text { resistance }\end{array}$ & $\begin{array}{l}\text { Drought } \\
\text { resistance }\end{array}$ & Hardiness $^{z}$ \\
\hline Acerpseudoplatanus & $\mathrm{ly}^{\mathrm{y}}$ & $\mathrm{h}^{\mathrm{x}, \mathrm{w}}$ & $1^{\mathrm{z}, \mathrm{v}}$ & $\mathrm{h}$ \\
\hline Ailanthus altissima & $\mathrm{h}^{\mathrm{u}, \mathrm{t}}$ & $h^{s, x}$ & $\mathrm{~h}^{\mathrm{z}, \mathrm{t}, \mathrm{r}}$ & $\mathrm{m}$ \\
\hline Betula pendula & $h^{q, p}$ & $\mathrm{~m}^{\mathrm{x}}$ & $\mathrm{m}^{\mathrm{z}}$ & $\mathrm{h}$ \\
\hline Carpinus betulus & $\mathrm{h}^{\mathrm{u}}$ & $1^{\mathrm{x}, \mathrm{o}}$ & $\mathrm{m}^{\mathrm{z}}$ & $\mathrm{h}$ \\
\hline Ginkgo biloba & $\mathrm{h}^{\mathrm{u}}$ & $\mathrm{m}^{\mathrm{n}}$ & $\mathrm{h}^{\mathrm{z}}$ & $\mathrm{m}$ \\
\hline Platanus $\times$ hispanica & $\mathrm{h}^{\mathrm{m}}$ & $1^{1}$ & $\mathrm{~h}^{\mathrm{z}}$ & $\mathrm{m}$ \\
\hline Quercus robur & $1^{x, y, k, j}$ & $1^{\mathrm{o}, \mathrm{i}}$ & $1^{\mathrm{z}}$ & $\mathrm{h}$ \\
\hline Robinia pseudoacacia & $\mathrm{h}^{\mathrm{x}, \mathrm{u}, \mathrm{h}}$ & $\mathrm{h}^{\mathrm{h}}$ & $h^{z}$ & $\mathrm{~h}$ \\
\hline Tilia cordata & $\mathrm{lg}^{\mathrm{g}}$ & $\mathrm{h}^{\mathrm{h}, \mathrm{g}}$ & $1^{\mathrm{x}}$ & $\mathrm{h}$ \\
\hline${ }^{\mathrm{z}}$ Roloff et al. (2009) & & \multicolumn{3}{|c|}{${ }^{\mathrm{P}}$ Seco et al. (2007) } \\
\hline${ }^{x}$ Aasamaa et al. (2002) & & \multicolumn{3}{|c|}{${ }^{\circ}$ Antonellini and Mollema (2010) } \\
\hline x $\operatorname{Dirr}(1976)$ & & \multicolumn{3}{|c|}{ n. Takahashi et al. (2005) } \\
\hline w Turner et al. (1993) & & \multicolumn{3}{|c|}{${ }^{\mathrm{m}}$ De La Torre (2001) } \\
\hline v Sjöman et al. (2015) & & \multicolumn{3}{|c|}{${ }^{\mathrm{L}}$ Rose and Webber (2011) } \\
\hline 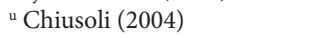 & & \multicolumn{3}{|c|}{${ }^{\mathrm{k}}$ Allen et al. (2010) } \\
\hline${ }^{t}$ Kowarik (2011) & & \multicolumn{3}{|c|}{ 'Wisniewski and Dickinson (2003) } \\
\hline${ }^{s}$ Karlik and Pittenger (2012) & & \multicolumn{3}{|c|}{${ }^{\text {i }}$ Sehmer et al. (1995) } \\
\hline${ }^{\mathrm{r}}$ Constán-Nava et al. (2010) & & \multicolumn{3}{|c|}{${ }^{\mathrm{h}}$ Sjöman and Busse Nielsen (2010) } \\
\hline${ }^{\mathrm{q}}$ Hartikainena et al. (2012) & & \multicolumn{3}{|c|}{ g Paludan-Müller et al. (2002) } \\
\hline
\end{tabular}


Table 4. Tree species' potential and/or suitability in various phytoremediation techniques; $h=h i g h, I=l o w, n . k .=$ unknown.

\begin{tabular}{|c|c|c|c|c|c|c|c|c|}
\hline Species & Bioindicator & $\mathrm{Pb}$ & $\mathrm{Cd}$ & $\mathrm{Cu}$ & $\mathrm{Zn}$ & Phytostabilization & Phytomanagement & $\begin{array}{l}\text { Foliar trapping } \\
\text { capacity }\end{array}$ \\
\hline Acer pseudoplatanus & $\mathrm{l}^{\mathrm{z}, \mathrm{y}, \mathrm{x}, \mathrm{w}, \mathrm{v}}$ & n.k. & $\mathrm{l}^{\mathrm{u}}$ & $\mathrm{l}^{\mathrm{u}} \mathrm{h}^{\mathrm{v}}$ & $\mathrm{h}^{\mathrm{v}, \mathrm{u}}$ & $\mathrm{h}^{\mathrm{t}}$ & (pioneer species) $^{s}$ & $\mathrm{~h}^{\mathrm{u}, \mathrm{r}}$ \\
\hline Ailanthus altissima & $\mathrm{h}^{\mathrm{q}, \mathrm{p}}$ & $1^{\mathrm{q}}$ & $\mathrm{lq}^{\mathrm{q}}$ & n.k. & $\mathrm{l}^{\mathrm{q}, \mathrm{p}}$ & n.k. & n.k. & $\mathrm{h}^{\mathrm{p}}$ \\
\hline Betula pendula & $\mathrm{h}^{\mathrm{z}, \mathrm{x}, \mathrm{w}, \mathrm{o}, \mathrm{n}, \mathrm{m}, 1}$ & $\mathrm{l}^{\mathrm{k}} \mathrm{h}^{\mathrm{z}, \mathrm{n}, 1}$ & $\mathrm{l}^{\mathrm{m}, \mathrm{l}, \mathrm{k}} \mathrm{h}^{\mathrm{z}, \mathrm{n}, \mathrm{j}}$ & $\mathrm{l}^{\mathrm{n}, 1}$ & $h^{w, n, 1, j}$ & $1^{1}$ & (pioneer species) $^{1}$ & $\mathrm{~h}^{\mathrm{z}, \mathrm{r}, 1, \mathrm{i}}$ \\
\hline Carpinus betulus & $\mathrm{l}^{\mathrm{y}, \mathrm{m}}$ & n.k. & n.k. & n.k. & n.k. & n.k. & n.k. & $h^{y, r, 1}$ \\
\hline Ginkgo biloba & $1^{\mathrm{s}, \mathrm{i}}$ & $\mathrm{l}^{\mathrm{h}}$ & n.k. & $\mathrm{l}^{\mathrm{h}}$ & $\mathrm{l}^{\mathrm{h}}$ & n.k. & n.k. & $1^{\mathrm{s}, \mathrm{h}}$ \\
\hline Platanus $\times$ hispanica & $1^{1}$ & $1^{1}$ & n.k. & $1^{1}$ & n.k. & n.k. & n.k. & $\mathrm{lg}^{\mathrm{g}} \mathrm{h}^{1}$ \\
\hline Quercus robur & $h^{z, y, x, f l o, w, e}$ & $\mathrm{l}^{\mathrm{e}}$ & $1^{\mathrm{e}}$ & $\mathrm{l}^{\mathrm{e}}$ & $\mathrm{l}^{\mathrm{e}} \mathrm{h}^{1}$ & $1^{x}$ & n.k. & $\mathrm{h}^{\mathrm{r}, 1}$ \\
\hline Robinia pseudoacacia & $\mathrm{h}^{\mathrm{z}, \mathrm{y}, \mathrm{w}, \mathrm{q}, \mathrm{l}, \mathrm{d}, \mathrm{c}, \mathrm{b}, \mathrm{a},{ }^{*}}$ & 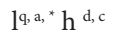 & $\mathrm{l}^{\mathrm{q}, \mathrm{d}, \mathrm{c}, \mathrm{a},{ }^{*}}$ & $\mathrm{~h}^{\mathrm{d}, \mathrm{c},{ }^{*}} \mathrm{l}^{\mathrm{a}}$ & $\mathrm{l}^{\mathrm{q}, \mathrm{a}} \mathrm{h}^{\mathrm{d}, \mathrm{c}, *}$ & $h^{1, f}$ & $\left(\right.$ pioneer species) ${ }^{1}$ & $1^{s, r}$ \\
\hline Tilia cordata & $\mathrm{l}^{\mathrm{y}, \mathrm{o}, \mathrm{m}, \mathrm{k}}$ & $\mathrm{l}^{\mathrm{o}, \mathrm{k}, * *}$ & $1^{\mathrm{k}}$ & $1^{o} h^{k}$ & $1^{\circ}$ & n.k. & n.k. & $\mathrm{h}^{\mathrm{y}, \mathrm{g}, \mathrm{r}, \mathrm{i}}$ \\
\hline \multicolumn{4}{|c|}{${ }^{\mathrm{z}}$ Dmuchowski et al. (2011) } & \multicolumn{5}{|c|}{${ }^{1}$ Van Nevel et al. (2011) } \\
\hline \multicolumn{4}{|c|}{ y Kardel et al. (2011) } & \multicolumn{5}{|c|}{ k Tomašević et al. (2011) } \\
\hline \multicolumn{4}{|l|}{ x Kardel et al. (2012) } & \multicolumn{5}{|c|}{ jUnterbrunner et al. (2007) } \\
\hline \multicolumn{4}{|l|}{ w Pourrut et al. (2011) } & \multicolumn{5}{|c|}{${ }^{\mathrm{i}}$ Murakami et al. (2012) } \\
\hline \multicolumn{4}{|l|}{${ }^{v}$ Sawidis et al. (2011) } & \multicolumn{5}{|c|}{${ }^{\mathrm{h}}$ Xiao and McPherson (2011) } \\
\hline \multicolumn{4}{|l|}{ " Simon et al. (2011) } & \multicolumn{5}{|c|}{${ }^{\mathrm{g}}$ Dzierżanowski et al. (2012) } \\
\hline \multicolumn{4}{|c|}{${ }^{t}$ André et al. (2006) } & \multicolumn{5}{|c|}{${ }^{\mathrm{f}}$ Wisniewski and Dickinson (2003) } \\
\hline \multicolumn{4}{|c|}{${ }^{s}$ Neinhuis and Barthlott (1998) } & \multicolumn{5}{|c|}{ e Aboal et al. (2004) } \\
\hline \multicolumn{4}{|c|}{${ }^{\mathrm{r}} \mathrm{S} æ b \emptyset$ et al. (2012) } & \multicolumn{5}{|c|}{${ }^{\mathrm{d}}$ Çelik et al. (2005) } \\
\hline \multicolumn{4}{|l|}{${ }^{\mathrm{q}}$ Baycu et al. (2006) } & \multicolumn{5}{|c|}{${ }^{\mathrm{c}}$ Cicek and Koparal (2004) } \\
\hline \multicolumn{4}{|l|}{ p Wang et al. (2006) } & \multicolumn{5}{|c|}{${ }^{\mathrm{b}} \mathrm{Ji}$ et al. (2012) } \\
\hline \multicolumn{4}{|l|}{${ }^{\circ}$ Aničić et al. (2011) } & \multicolumn{5}{|c|}{ a Samecka-Cymerman et al. (2009) } \\
\hline \multicolumn{4}{|c|}{${ }^{\mathrm{n}}$ Evangelou et al. (2012) } & \multicolumn{5}{|c|}{${ }^{*}$ Serbula et al. (2012) } \\
\hline \multicolumn{4}{|c|}{ m Khavanin Zadeh et al. (2012) } & \multicolumn{5}{|c|}{${ }^{* *}$ Tomašević et al. (2013) } \\
\hline
\end{tabular}

organic aerosol, and particulate matter can be formed by the photochemically driven reaction between $\mathrm{NO}_{\mathrm{x}}$ and VOCs (Fehsenfeld et al. 1992; Fuentes et al. 2001; Calfapietra et al. 2013).

The choice of an emitting or non-emitting species might be important for the improvement of the air quality in urban environments. Abiotic stresses (e.g., mechanical injuries or drought) may induce a change of constitutive BVOCs, either stimulating or quenching the emissions, or may induce de novo synthesis and emission. Induced emissions may occur in a systemic way-i.e., away from the site of damage (Loreto and Schnitzler 2010). The emission of BVOCs is biosynthetically controlled by abiotic factors, such as light and/or temperature, atmospheric $\mathrm{CO}_{2}$ concentration, or nutrition. Trees in urban environments can be either particularly subjected to stresses related to temperature variations, drought and salt, herbivore or pathogen attack, alone, or in combination (Loreto and Schnitzler 2010). Emission of volatile isoprenoids is a metabolic cost for plants, but benefits involve an improvement of thermotolerance and higher antioxidant capacity (Loreto and Schnitzler 2010; Tattini et al. 2015). Indeed, plants may use volatile isoprenoids as a fast response mechanism to cope with environmental constraints (Loreto et al. 2014). How-
Table 5. Tree allergenicity and VOCs emission capacity; h = high, I = low.

\begin{tabular}{lcc}
\hline Species & Allergenicity & VOCs emission \\
\hline Acer pseudoplatanus & $\mathrm{h}^{\mathrm{z}}$ & $\mathrm{l}^{\mathrm{y}}$ \\
Ailanthus altissima & $\mathrm{h}^{\mathrm{z}, \mathrm{x}, \dagger}$ & $\mathrm{l}^{\mathrm{w}}$ \\
Betula pendula & $\mathrm{h}^{\mathrm{z}, \mathrm{x}}$ & $\mathrm{l}^{\mathrm{w}}$ \\
Carpinus betulus & $\mathrm{h}^{\mathrm{z}, \mathrm{x}}$ & $\mathrm{l}^{\mathrm{w}}$ \\
Ginkgo biloba & $\mathrm{h}^{\mathrm{z}, \mathrm{x}, \dagger}$ & $\mathrm{l}^{\mathrm{w}, \mathrm{v}}$ \\
Platanus $\times$ hispanica & $\mathrm{h}^{\mathrm{x}}$ & $\mathrm{l}^{\mathrm{w}} \mathrm{h}^{\mathrm{w}}$ \\
Quercus robur & $\mathrm{h}^{\mathrm{z}, \mathrm{x}}$ & $\mathrm{h}^{\mathrm{w}, \mathrm{v}}$ \\
Robinia pseudoacacia & $\mathrm{h}^{\mathrm{z}}$ & $\mathrm{h}^{\mathrm{w}, \mathrm{v}}$ \\
Tilia cordata & $\mathrm{h}^{\mathrm{z}}$ & $\mathrm{l}^{\mathrm{y}}$ \\
\hline${ }^{\mathrm{z}}$ Ogren (2000) & \\
${ }^{\mathrm{y}}$ Karl et al. (2009) & \\
${ }^{\mathrm{x}}$ Carinanos and Casares-Porcell (2011) & \\
${ }^{\mathrm{w}}$ Loreto et al. (2014) & \\
${ }^{\mathrm{w}}$ Kesselmeier and Staudt (1999) & & \\
${ }^{\mathrm{v}}$ Benjamin and Winer (1998) & & \\
${ }^{\dagger}$ Female & &
\end{tabular}

ever, in the choice of the tree species in urban areas, it is important to consider that a species can emit VOCs, but that this disservice can be counterbalanced by the services it provides.

\section{CONCLUSIONS}

This review has provided a comprehensive assessment of tree species suitable for phytoremediation in the urban environment. Due to physiological and morphological characteristics and to the intrinsic tolerance to several stress factors, some species seem particularly promising as an indicator of the environmental 
state of an urban environment and to lower the amount of specific pollutants. It must also be pointed out that intrinsic species properties (e.g., tolerance and/or bioindication capacity for a specific contaminant) can help planners to create an effective monitoring net in strategic points of a city, or to detect single contaminants representative of a specific anthropogenic impact. Actually, only implementing largerscale projects will help determine whether green infrastructure will have measurable effects on climate, air and water quality, and human health at a municipal scale (Pataki et al. 2011). Furthermore, those trees can be also used for ecosystem restoration (see Zerbe and Wiegleb 2009). The selection of species and the management practices with regard to phytoremediation should promote a sustainable urban development to mitigate pollution in order to achieve a healthier urban environment.

There are several successful examples of phytoremediation projects in cities, as stated by Felson and Pickett (2005), Kirkwood (2011), Sousa (2003), and Wilschut et al. (2013). For example, a field of birch trees was used to remediate the soil on the site of the former blast furnaces of Duisburg-Nord Park in Germany (Felson and Pickett 2005). However, only limited information is available about project performance and timeframes for project completion (Oh et al. 2014).

Acknowledgments. This study was financially supported by the Italian Ministry of Research and University (MIUR) with the National Research Project (PRIN) 2009 "Molecular, physiological, and morphological aspects of ornamentals response to sub-optimal water resources and ionic stress."

\section{LITERATURE CITED}

Aasamaa, K., A. Sober, W. Hartung, and Ü. Niinemets. 2002. Rate of stomatal opening, shoot hydraulic conductance, and photosynthetic characteristics in relation to leaf abscisic acid concentration in six temperate deciduous trees. Tree Physiology 22(4):267-276

Aboal, J.R., J.A. Fernández, and A. Carballeira. 2004. Oak leaves and pine needles as biomonitors of airborne trace elements pollution. Environmental and Experimental Botany 51:215-225.

Allen, C.D., A.K. Macalady, H.Chenchouni, D. Bchelet, N. McDowell, M. Vennetier, T. Kitzberger, et al. 2010. A global overview of drought and heat-induced tree mortality reveals emerging climate change risks for forests. Forest Ecology and Management 259:660-684.
Amato, F., M. Pandolfi, M. Viana, X. Querol, A. Alastuey, and T. Moreno. 2009. Spatial and chemical patterns of PM10 in road dust deposited in urban environment. Atmospheric Environment 43:1650-1659.

André, O., P.S. Vollenweider, and M. Günthardt-Goerg. 2006. Foliar response to heavy metals in sycamore maple (Acer pseudoplatanus L.). Forest Snow and Landscape Research 80(3):275-288.

Aničić, M., T. Spasić, M. Tomašević, S. Rajšić, and M. Tasić. 2011. Trace elements accumulation and temporal trends in leaves of urban deciduous trees (Aesculus hippocastanum and Tilia spp.). Ecological Indicators 11:824-830.

Antonellini, M., and P.N. Mollema. 2010. Impact of groundwater salinity on vegetation species richness in the coastal pine forests and wetlands of Ravenna, Italy. Ecological Engineering 36(9):1201-1211.

Baker, A.J.M. 1981. Accumulators and excluders strategies in the response of plants to heavy metals. Journal of Plant Nutrition 3(1-4):643-654.

Baker, A.J.M., S.P. McGrath, C.M.D. Sidoli, and R.D. Reeves. 1994. The possibility of in situ heavy metal decontamination of polluted soils using crops of metal-accumulating plants. Resources, Conservation, and Recycling 11(1-4):41-49.

Baker, A.J.M., S.P. McGrath, R.D. Reeves, and J.A.C. Smith. 2000. Metal accumulators plants: A review of the ecology and physiology of a biological resource for phytoremediation of metalpolluted soils. pp. 85-107. In: N. Terry and G.S. Banuelos (Eds.). Phytoremediation of contaminated soil and water. CRC Press, Boca Raton, Florida, U.S.

Baumann, A. 1885. Das verhalten von zinksalzen gegen pflanzen und im boden. Landwirtsch. Vers 31:1-53.

Baycu, G., D. Tolunay, H. Özden, and S. Günebakan. 2006. Ecophysiological and seasonal variations in $\mathrm{Cd}, \mathrm{Pb}, \mathrm{Zn}$, and $\mathrm{Ni}$ concentrations in the leaves of urban deciduous trees in Istanbul. Environmental Pollution 143:545-554.

Beckett, K.P., P. Freer-Smith, and G. Taylor. 2000. Effective tree species for local air quality management. Journal of Arboriculture 26(1):12-19.

Beckett, K.P., P.H. Freer-Smith, and G. Taylor. 1998. Urban woodlands: Their role in reducing the effects of particulate pollution. Environmental Pollution 99:347-360.

Bell, J.N.B., S.L. Honour, and S.A. Power. 2011. Effects of vehicle exhaust emissions on urban wild plant species. Environmental Pollution 159:1984-1990.

Benjamin, M.T., and A.M. Winer. 1998. Estimating the ozoneforming potential of urban trees and shrubs. Atmospheric Environment 32(1):53-68

Bothe, H. 2011. Plants in Heavy Metal Soils. pp. 35-57. In: I. Sherameti and A. Varma (Eds.). Detoxification of Heavy Metals. Springer, Berlin, Heidelberg, Germany.

Bradshaw, A., B. Hunt, and T. Walmsley. 1995. Trees in the Urban Landscape. Principles and Practice. E. \& F.N. Spon, London, UK. 272 pp.

Brooks, R.R, J. Lee, R.D. Reeves, and T. Jaffre. 1977. Detection of nickeliferous rocks by analysis of herbarium specimens of indicator plants. Journal of Geochemical Exploration 7:49-57.

Brooks, R.R. 1994. Plants that hyperaccumulate heavy metals. pp. 88-102. In: M.E. Farago (Ed.). Plants and the Chemical Elements: Biochemistry, Uptake, Tolerance, and Toxicity. VCH, Weinheim, Germany. 
Brunner, I., J. Luster, M.S. Günthardt-Goerg, and B. Frey. 2008 Heavy metal accumulation and phytostabilization potential of tree fine roots in a contaminated soil. Environmental Pollution 152:559-568.

Buccolieri, R., S.M. Salim, L.S. Leo, and S. Di Sabatino. 2011. Analysis of local scale tree atmosphere interaction on pollutant concentration in idealized street canyons and application to a real urban junction. Atmospheric Environment 45:1702-1713.

Burger, J. 2006. Bioindicators: A review of their use in the environmental literature: 1970-2005. Environmental Bioindicators 1(2):136-144.

Calfapietra, C., S. Fares, and F. Loreto. 2009. Volatile organic compounds from Italian vegetation and their interaction with ozone. Environmental Pollution 157:1478-1486.

Calfapietra, C., S. Fares, F. Manes, A. Morani, G. Sgrigna, and F. Loreto. 2013. Role of biogenic volatile organic compounds (BVOCs) emitted by urban trees on ozone concentration in cities: A review. Environmental Pollution 183:71-80.

Calvo, A.I., C. Alves, A. Castro, V. Pont, A.M. Vicente, and R. Fraile. 2013. Research on aerosol sources and chemical composition: Past, current, and emerging issues. Atmospheric Research 120121:1-28

Carinanos, P., and M. Casares-Porcel. 2011. Urban green zones and related pollen allergy: A review. Some guidelines for designing spaces with low allergy impact. Landscape and Urban Planning 101:205-214.

Çelik, A., A.A. Kartal, A. Akdoğan, and Y. Kafka. 2005. Determining the heavy metal pollution in Denizli (Turkey) by using Robinia pseudoacacia L. Environment International 31(1):105-112.

Chiusoli, A. 2004. Il verde nelle aree urbane. In: Pirani, A. Il verde in città, La progettazione del verde negli spazi urbani. Edagricole, Bologna, Italy. 525 pp.

Cicek, A., and A.S. Koparal. 2004. Accumulation of sulfur and heavy metals in soil and tree leaves sampled from the surroundings of Tunçbilek Thermal Power Plant. Chemosphere 57:1031-1036.

Città di Torino. 2006. Regolamento del verde pubblico e privato della Città di Torino. Allegato VII (Cap III). <www.comune.torino. it/regolamenti/317/317_all2.htm\#all07>

Comune di Bolzano. 2010. Catasto degli alberi. Servizio Giardineria Comunale. Ufficio Tutela dell'Ambiente e del Territorio.

Comune di Merano. 2012. Catasto degli alberi. <www.ambiente. comune.merano.bz.it/alberi/search>

Comune di Padova. 2013. Gli alberi di Padova. Alberi stradali. $<$ www.padovanet.it $/$ dettaglio.jsp? tasstipo $=$ C\&tassid $=2288 \&$ id $=16753 \#$. UbbvOBVBvIW $>$

Constán-Nava, S., A. Bonet, E. Pastor, and M.J. Lledó. 2010. Longterm control of the invasive tree Ailanthus altissima: insights from Mediterranean protected forests. Forest Ecology and Management 260(6):1058-1064.

Daily, G.C. 1995. Restoring Value to the World's Degraded Lands. Science 269(5222):350-354.

de Kok, T.M.C.M., H.A.L. Driece, J.G.F. Hogervorst, and J.J. Briede. 2006. Toxicological assessment of ambient and traffic-related particulate matter: A review of recent studies. Mutation Research 613:103-122.

De La Torre, J.R. 2001. Árboles y arbustos de la España peninsular. Ediciones Mundi-Prensa. 512 pp.

de Sousa, C.A. 2003. Turning brownfields into green space in the City of Toronto. Landscape and Urban Planning 62(4):181-198.
Dickinson, N.M. 2002. Phytoremediation of industrially contaminated sites using trees. In: J.-L. Morel, G. Echevarria, and N. Goncharova (Eds.). Phytoremediation of Metal-Contaminated Soils. Nato Science Series. IV. Earth and Environmental Sciences-Vol. 68. Springer, Germany. 346 pp.

Dickinson, N.M., A.P. Turner, and N.W. Lepp. 1991. How do trees and other long-lived plants survive in polluted environments? Functional Ecology 5:5-11.

Dirr, M.A. 1976. Selection of trees for tolerance to salt injury. Journal of Arboriculture 2(11):209-216.

Dmuchowski, W., D. Gozdowski, and A.H. Baczewska. 2011. Comparison of four bioindication methods for assessing the degree of environmental lead and cadmium pollution. Journal of Hazardous Materials 197:109-118.

Dobbs, C., F. Escobedo, and W. Zipperer. 2011. A framework for developing urban forest ecosystem services and goods indicators. Landscape and Urban Planning 99(3-4):196-206.

Domínguez, M.T., P. Madejon, T. Maranon, and J.M. Murillo. 2008. Afforestation of a trace element pollution area in SW Spain: Woody plants performance and trace element accumulation. European Journal of Forest Research 129:47-59.

Duong, T.T.T., and B.-K. Lee. 2011. Determining contamination level of heavy metals in road dust from busy traffic areas with different characteristics. Journal of Environmental Management 92(3):554-62.

Dzierżanowski, K., R. Popek, H. Gawrońska, A. Sæbø, and S.W. Gawroński. 2011. Deposition of particulate matter of different size fractions on leaf surfaces and in waxes of urban forest species. International Journal of Phytoremediation 13(10):1037-1046.

Escobedo, F.J., T. Kroeger, and J.E. Wagner. 2011. Urban forests and pollution mitigation: Analyzing ecosystem services and disservices. Environmental Pollution 159:2078-2087.

Evangelou, M.W.H., A. Deram, A. Gogos, B. Studer, and R. Schulin. 2012. Assessment of suitability of tree species for the production of biomass on trace element contaminated soils. Journal of Hazardous Materials 209-210:233-239.

Fehsenfeld, F., J. Calvert, R. Fall, P. Goldan, A.B. Guenther, C.N. Hewitt, B. Lamb, et al. 1992. Emissions of volatile organic compounds from vegetation and the implications for atmospheric chemistry. Global Biogeochemical Cycles 6(4):389-430.

Felson, A.J., and S.T.A. Pickett. 2005. Designed experiments: New approaches to studying urban ecosystems. Frontiers in Ecology and the Environment 3(10):549.

Ferrari, M., and D. Medici. 1998. Alberi e arbusti in Italia. Manuale di Riconoscimento. Edagricole, Bologna, Italy. 967 pp.

Fuentes, J.D., B.P. Hayden, M. Garstang, M. Lerdau, D. Fitzjarrald, D.D. Baldocchi, R. Monson, et al. 2001. New Directions? VOCs and biosphere-atmosphere feedbacks. Atmospheric Environment 35:189-191.

Fujiwara, F., R. Jiménez Rebagliati, L. Dawidowski, D. Gómez, G. Polla, V. Pereyra, and P. Smichowski. 2011. Spatial and chemical patterns of size fractionated road dust collected in a megacity. Atmospheric Environment 45(8):1497-1505.

Fujiwara, F.G., D.R. Gómez, L. Dawidowski, P. Perelman, and A. Faggi. 2011. Metals associated with airborne particulate matter in road dust and tree bark collected in a megacity (Buenos Aires, Argentina). Ecological Indicators 11:240-247. 
Gardea-Torresdey, J., J. Peraltavidea, G. Delarosa, and J. Parsons. 2005. Phytoremediation of heavy metals and study of the metal coordination by X-ray absorption spectroscopy. Coordination Chemistry Reviews 249(17-18):1797-1810.

Gatti, E. 2008. Micropropagation of Ailanthus altissima and in vitro heavy metal tolerance. Biologia Plantarum 52(1):146-148.

Georgi, J.N., and D. Dimitriou. 2010. The contribution of urban green spaces to the improvement of environment in cities: Case study of Chania, Greece. Building and Environment 45:1401-1414.

Gómez-Baggethun, E., and D.N. Barton. 2013. Classifying and valuing ecosystem services for urban planning. Ecological Economics 86:235-245.

Gunawardena, J., P. Egodawatta, G.A. Ayoko, and A. Goonetilleke. 2013. Atmospheric deposition as a source of heavy metals in urban storm water. Atmospheric Environment 68:235-242.

Gupta, S.K., T. Herren, K. Wenger, R. Krebs, and T. Hari. 2000. In situ gentle remediation measures for heavy metals-polluted soils. In: N. Terry and G.S. Bañuelos (Eds.). Phytoremediation of Contaminated Soil and Water. CRC Press LLC, Boca Raton, Florida, U.S. 380 pp.

Harris, R.W., J.R. Clark, and N.P. Matheny. 1999. Arboriculture, Integrated Management of Landscape Trees, Shrubs, and Vines, third edition. Prentice Hall, Upper Saddle River, New Jersey, U.S. 687 pp.

Hartikainena, K., J. Riikonena, A.-M. Nerga, M. Kivimäenpääa, V. Ahonenb, A. Tervahautab, S. Kärenlampib, et al. 2012. Impact of elevated temperature and ozone on the emission of volatile organic compounds and gas exchange of silver birch (Betula pendula Roth). Environmental and Experimental Botany 84:33-43.

Hermle, S., M.S. Günthardt-Goerg, and R. Schulin. 2006. Effects of metal-contaminated soil on the performance of young trees growing in model ecosystems under field conditions. Environmental Pollution 144:703-714.

Ji, J., N. Kokutse, M. Genet, T. Fourcaud, and Z. Zhang. 2012. Effect of spatial variation of tree root characteristics on slope stability. A case study on black locust (Robinia pseudoacacia) and arborvitae (Platycladus orientalis) stands on the Loess Plateau, China. Catena 92:139-154.

Kardel, F., K. Wuyts, B.A. Maher, R. Hansard, and R. Samson. 2011. Leaf saturation isothermal remanent magnetization (SIRM) as a proxy for particulate matter monitoring: Inter-species differences and in-season variation. Atmospheric Environment 45:5164-5171.

Kardel, F., K. Wuyts, M. Babanezhad, T. Wuytack, S. Adriaenssens, and R. Samson. 2012. Tree leaf wettability as passive bio-indicator of urban habitat quality. Environmental and Experimental Botany 75:277-285.

Karl, M., A. Guenther, R. Köble, A. Leip, and G. Seufert. 2009. A new European plant-specific emission inventory of biogenic volatile organic compounds for use in atmospheric transport models. Biogeosciences 6:1059-1087.

Karlik, J.F., and D.R. Pittenger.2012. Urban trees and ozone formation: A consideration for large-scale plantings. University of California. Agriculture and Natural Resources. Publication 8484. <http://anrcatalog.ucdavis.edu/pdf/8484.pdf>

Kesselmeier, J., and M. Staudt. 1999. Biogenic Volatile Organic Compounds (VOCs): An overview on emission, physiology, and ecology. Journal of Atmospheric Chemistry 33(1):23-88.
Khavanin Zadeh, A.R., F. Veroustraete, K. Wuyts, F. Kardel, and R. Samson. 2012. Dorsi-ventral leaf reflectance properties of Carpinus betulus L.: An indicator of urban habitat quality. Environmental Pollution 162:332-337.

Kirkwood, N. 2011. Manufactured Sites: Rethinking the PostIndustrial Landscape, reprint edition. Taylor \& Francis, London UK. 272 pp.

Konijnendijk, C., M. Annerstedt, A.B. Nielsen, and S. Maruthaveeran. 2013. Benefits of Urban Parks. A systematic review. A Report for IFPRA. Copenhagen \& Alnarp, Sweden. 70 pp.

Kowarik, I., and I. Säumel. 2007. Biological flora of Central Europe: Ailanthus altissima (Mill.) Swingle. Perspectives in Plant Ecology, Evolution, and Systematics 8:207-237.

Lõhmus, K., A. Kull, J. Truu, M. Truu, E. Kaar, I. Ostonen, S. Meel, et al. 2007. The reclamation of the North Estonian oil shale mining area. In: Ü. Mander, H. Wiggering, and K. Helming (Eds.). Multifunctional Land Use, Meeting Future Demands for Landscape Goods and Services. Springer, Berlin, Heidelberg, New York. 403 pp.

Loreto, F., and J.-P. Schnitzler. 2010. Abiotic stresses and induced BVOCs. Trends in Plant Science 15(3):154-166.

Loreto, F., S. Pollastri, S. Fineschi, and V. Velikova. 2014. Volatile isoprenoids and their importance for protection against environmental constraints in the Mediterranean area. Environmental and Experimental Botany 103:99-106.

Lyytimäki, J. 2014. Bad nature: Newspaper representations of ecosystem disservices. Urban Forestry \& Urban Greening 13(3):418-424.

Lyytimäki, J., and M. Sipilä. 2009. Hopping on one leg-The challenge of ecosystem disservices for urban green management. Urban Forestry \& Urban Greening 8:309-315.

Malek, von J., and H. Wawrik. 1985. Baumpflege. Pflanzung und Pflege von Strassenbäumen. Landschafts- und Grünplanung. Ulmer Verlag, Stuttgart, Germany.

Manousaki, E., and N. Kalogerakis. 2011. Halophytes present new opportunities in phytoremediation of heavy metals and saline soils. Industrial and Engineering Chemical Research 50:656-660.

Markert, B. 2008. Bioindication and biomonitoring as innovative biotechniques for controlling trace metal influence to the environment. pp. 743-760. In: M.N.V. Prasad (Ed.). Trace elements as contaminants and nutrients. Consequences in ecosystems and human health. Wiley, Hoboken, New Jersey, U.S.

Marziliano, P.A., R. Lafortezza, G. Colangelo, D. Clive, and G. Sanesi. 2013. Structural diversity and height growth models in urban forest plantations: A case study in northern Italy. Urban Forestry \& Urban Greening 12:246-254.

McBride, J.R., and V. Douhovnikoff. 2012. Characteristics of the urban forests in arctic and near-arctic cities. Urban Forestry \& Urban Greening 11:113-119.

Meers, E., B. Vandecasteele, A. Ruttensc, J. Vangronsveld, and F.M.G. Tack. 2007. Potential of five willow species (Salix spp.) for phytoextraction of heavy metals. Environmental and Experimental Botany 60:57-68.

Monaci, F., E.O. Leidi, M.D. Mingorance, B. Valdes, S.R. Oliva, and R. Bargagli. 2011. Selective uptake of major and trace elements in Erica andevalensis, an endemic species to extreme habitats in the Iberian Pyrite Belt. Journal of Environmental Sciences 23(3):444-452. 
Mulligan, C.N., R.N. Yong, and B.F. Gibbs. 2001. Remediation technologies for metal-contaminated soils and groundwater: An evaluation. Engineering Geology 60:193-207.

Murakami, M., M. Abe, Y. Kakumoto, H. Kawano, H. Fukasawa, M. Saha, and H. Takada. 2012. Evaluation of Ginkgo as a biomonitor of airborne polycyclic aromatic hydrocarbons. Atmospheric Environment 54:9-17.

Neinhuis, C., and W. Barthlott. 1998. Characterization and distribution of water repellent, self-cleaning plant surface. Annals of Botany 79:667-677.

Nowak, D. J., and J.F. Dwyer. 2007. Understanding the benefits and costs of urban forest ecosystems. pp. 25-46. In: J.E. Kuser (Ed.). Urban and Community Forestry in the Northeast. Springer, Dordrecht, Netherlands.

Nowak, D. J., D.E. Crane, and J.C. Stevens. 2006. Air pollution removal by urban trees and shrubs in the United States. Urban Forestry \& Urban Greening 4:115-123.

Nowak, D.J., S. Hirabayashi, A. Bodine, and E. Greenfield. 2014. Tree and forest effects on air quality and human health in the United States. Environmental Pollution 193:119-129.

Odone, P. 1992. Il verde urbano. La Nuova Italia Scientifica. Roma, Italy. $274 \mathrm{pp}$.

Ogren, T.L. 2000. Allergy free gardening. Ten Speed Press, Berkeley, California, U.S. 267 pp.

Oh, K., T. Cao, T. Li, and H. Cheng. 2014. Study on application of phytoremediation technology in management and remediation of contaminated soils. Journal of Clean Energy Technologies 2(3):216-220.

Paludan-Müller, G., H. Saxe, L.B. Pedersen, and R.T. Barfoed. 2002. Differences in salt sensitivity of four deciduous tree species to soil or airborne salt. Physiologia Plantarum 114:223-230.

Paoletti, E. 2009. Ozone and urban forests in Italy. Environmental Pollution 157:1506-1512.

Papa, S., G. Bartoli, F. Nacca, B. D’Abrosca, E. Cembrola, A. Pellegrino, and A. Fioretto. 2012. Trace metals, peroxidase activity, PAHs contents, and ecophysiological changes in Quercus ilex leaves in the urban area of Caserta (Italy). Journal of Environmental Management 113:501-509.

Pataki, D.E., M.M. Carreiro, J. Cherrier, N.E. Grulke, V. Jennings, S. Pincetl, R.V. Pouyat, et al. 2011. Coupling biogeochemical cycles in urban environments: Ecosystem services, green solutions, and misconceptions. Frontiers in Ecology and the Environment 9(1):27-36

Pauleit, S., N. Jones, G. Garcia-Martin, J.L. Garcia-Valdecantos, L.M. Rivière, L. Vidal-Beaudet, and T.B. Randrup. 2002. Tree establishment practice in towns and cities: Results from a European survey. Urban Forestry \& Urban Greening 1(2):83-96.

Pauleit, S., N. Jones, S. Nyhuus, J. Pirnat, and F. Salbitano. 2005. Urban forest resources in European cities. pp. 49-80. In: C.C. Konijnendijk, J. Schipperijn, and K. Nilsson (Eds.). COST Action E12 - Urban forests and trees - Proceedings No 2.

Pellegrini, E., G. Lorenzini, S. Loppi, and C. Nali. 2014. Evaluation of the suitability of Tillandsia usneoides (L.) L. as biomonitor of airborne elements in an urban area of Italy, Mediterranean basin. Atmospheric Pollution Research 5(2):226-235.

Peuke, A.D., and H. Rennenberg. 2005. Phytoremediation with transgenic trees. Zeitschrift für Naturforschung C 60134):199-207.
Pilon-Smits, E.A.H., and J.L. Freeman. 2006. Environmental cleanup using Plants: Biotechnological advances and ecological considerations. Frontiers in Ecology and the Environment 4:203-210.

Pourrut, B., A. Lopareva-Pohu, T.C. Pruvo, G. Garçon, A. Verdin, C. Waterlo, G. Bidar, P. Shirali, and F. Douay. 2011. Assessment of fly ash-aided phytostabilization of highly contaminated soils after an eight-year field trial. Part 2. Influence on plants. Science of the Total Environment 409(21):4504-4510.

Pulford, I.D., and C. Watson. 2003. Phytoremediation of heavymetal-contaminated land by trees: A review. Environment International 29(4):529-540.

Punshon, T., and N.M. Dickinson. 1997. Acclimation of Salix to metal stress. New Phytologist 137:303-314.

Rajkumar, M., S. Sandhya, M.N.V. Prasad, and H. Freitas. 2012. Perspectives of plant-associated microbes in heavy metal phytoremediation. Biotechnology Advances 30(6):1562-1574.

Rascio, N., and F. Navari-Izzo. 2011. Heavy metal hyperaccumulating plants: How and why do they do it? And what makes them so interesting? Plant Science 180:169-181.

Raskin, I., R.D. Smith, and D.E. Salt. 1997. Phytoremediation of metals: Using plants to remove pollutants from the environment. Current Opinions in Biotechnology 8(2):221-226.

Roloff, A., S. Korn, and S. Gillner. 2009. The Climate-Speciesmatrix to select tree species for urban habitats considering climate change. Urban Forestry \& Urban Greening 8:295-308.

Rose, D., and J. Webber. 2011. De-icing salt damage to trees. Forest Research. Pathology Advisory Note (No. 11). <www.forestry. gov.uk/pdf/pathology_note11.pdf/\$file/pathology_note11.pdf>

Rosenvald, K., T. Kuznetsova, I. Ostonen, M. Truu, J. Truu, V. Uri, and K. Lohmus. 2011. Rhizosphere effect and fine-root morphological adaptations in a chronosequence of silver birch stands on reclaimed oil shale post-mining areas. Ecological Engineering 37:1027- 1034 .

Rosselli, W., C. Keller, and K. Boschi. 2003. Phytoextraction capacity of trees growing on a metal contaminated soil. Plant and Soil 256(2):265-272.

Roy, S., J. Byrne, and C. Pickering. 2012. A systematic quantitative review of urban tree benefits, costs, and assessment methods across cities in different climatic zones. Urban Forestry \& Urban Greening 11(4):351-363.

Russo, A., F.J. Escobedo, and S. Zerbe. 2016. Quantifying the localscale ecosystem services provided by urban treed streetscapes in Bolzano, Italy. AIMS Environmental Science 3(1):58-76.

Russo, A., F.J. Escobedo, N. Timilsina, A.O. Schmitt, S. Varela, and S. Zerbe. 2014. Assessing urban tree carbon storage and sequestration in Bolzano, Italy. International Journal of Biodiversity Science, Ecosystem Services \& Management 10(1):54-70.

Sæbø, A., R. Popek, B. Nawrot, and H.M. Hanslin. 2012. Plant species differences in particulate matter accumulation on leaf surfaces. Science of the Total Environment 427-428:347-354.

Salt, D.E., M. Blaylock, N.P.B.A. Kumar, V. Dushenkov, B.D. Ensley, I. Chet, and I. Raskin. 1995. Phytoremediation: A novel strategy for the removal of toxic metals from the environment using plants. Nature Biotechnology 13:468-474.

Salt, D.E., R.D. Smith, and I. Raskin. 1998. Phytoremediation. Annual Review of Plant Physiology and Plant Molecular Biology 49:643-68. 
Samecka-Cymerman, A., A. Stankiewicza, K. Kolona, and A.J. Kempers. 2009. Self-organizing feature map (neural networks) as a tool to select the best indicator of road traffic pollution (soil, leaves, or bark of Robinia pseudoacacia L.). Environmental Pollution 157:2061-2065.

Sarma, H. 2011. Metal hyperaccumulation in plants: A review focusing on phytoremediation technology. Journal of Environmental Science and Technology 4:118-138.

Sawidis, T., J. Breuste, M. Mitrovic, P. Pavlovic, and K. Tsigaridas. 2011. Trees as bioindicator of heavy metal pollution in three European cities. Environmental Pollution 159(12):3560-3570.

Seco, R., J. Peñuelas, and I. Filella. 2007. Short-chain oxygenated VOCs: Emission and uptake by plants and atmospheric sources, sinks, and concentrations. Atmospheric Environment 41:2477-2499.

Sehmer, L., B. Alaoui-Sosse, and P. Dizengremel. 1995. Effect of salt stress on growth and on the detoxifying pathway of pedunculate oak seedlings (Quercus robur L.). Plant Physiology 147:144-151.

Semenzato, P., D. Cattaneo, and M. Dainese. 2011. Growth prediction for five tree species in an Italian urban forest. Urban Forestry \& Urban Greening 10:169-176.

Serbula, S.M., D.M. Dusanka, R.M. Kovacevic, and A.A. Ilic. 2012. Assessment of airborne heavy metal pollution using plant parts and topsoil. Ecotoxicology and Environmental Safety 76:209-214.

Simon, E., B. Mihály, A. Vidic, D. Bogyó, I. Fábián, and B. Tóthmérés. 2011. Air pollution assessment based on elemental concentration of leaves tissue and foliage dust along an urbanization gradient in Vienna. Environmental Pollution 159:1229-1233.

Sjöman H., and A.B. Nielsen. 2010. Selecting trees for urban paved sites in Scandinavia-A review of information on stress tolerance and its relation to the requirements of tree planners. Urban Forestry \& Urban Greening 9:281-293.

Sjöman, H., A.D. Hirons, and N.L. Bassuk. 2015. Urban forest resilience through tree selection-Variation in drought tolerance in Acer. Urban Forestry \& Urban Greening 14(4):858-865.

Sjöman, H., J. Östberg, and O. Bühler. 2012. Diversity and distribution of the urban tree population in ten major Nordic cities. Urban Forestry \& Urban Greening 11(1):31-39.

Strohbach, M.W., E. Arnold, and D. Haase. 2012. The carbon footprint of urban green space-A life cycle approach. Landscape and Urban Planning 104(2):220-229.

Takahashi, M., A. Higaki, M. Nohno, M. Kamada, Y. Okamura, K. Matsui, S. Kitani, and H. Morikawa. 2005. Differential assimilation of nitrogen dioxide by 70 taxa of roadside trees at an urban pollution level. Chemosphere 61(5):633-639.

Tattini, M., F. Loreto, A. Fini, L. Guidi, C. Brunetti, V. Velikova, A. Gori, and F. Ferrini. 2015. Isoprenoids and phenylpropanoids are part of the antioxidant defense orchestrated daily by drought-stressed Platanus $\times$ acerifolia plants during Mediterranean summers. New Phytologist 207(3):613-26.

Tomašević, M., D. Antanasijević, M. Aničić, I. Deljanin, A. PerićGrujić, and M. Ristić. 2013. Lead concentrations and isotope ratios in urban tree leaves. Ecological Indicators 24:504-509.

Tomašević, M., M. Aničić, L. Jovanovic, A. Perić-Grujić, and M. Ristić. 2011. Deciduous tree leaves in trace elements biomonitoring: A contribution to methodology. Ecological Indicators 11(6):1689-1695.
Traidl-Hoffmann, C., A. Kasche, A. Menzel, T. Jakob, M. Thiel, J. Ring, and H. Behrendt. 2003. Impact of pollen on human health: More than allergen carriers? International Archives of Allergy and Immunology 131:1-13.

Trees for Cities. 2014. Best practice guidelines how to assess the suitability of a site for street trees planting and what to do next. <www.treesforcities.org/index.php/download_file/372/141>

Turner, A.P., and N.M. Dickinson. 1993. Survival of Acer pseudoplatanus L. (sycamore) seedlings on metalliferous soils. New Phytologist 123:509-521.

Ugolini, F., R. Tognetti, A. Raschi, and L. Bacci. 2013. Quercus ilex L. as bioaccumulator for heavy metals in urban areas: Effectiveness of leaf washing with distilled water and considerations on the tree's distance from traffic. Urban Forestry \& Urban Greening 12(4):576-584.

United States Department of Agriculture. 2012. Field Guide for Managing Tree-of-heaven in the Southwest. <www.fs.usda.gov/ Internet/FSE_DOCUMENTS/stelprdb5410131.pdf>

Unterbrunner, R., M. Puschenreiter, P. Sommer, G. Wieshammer, P. Tlustoš, M. Zupan, and W.W. Wenzel. 2007. Heavy metal accumulation in trees growing on contaminated sites in Central Europe. Environmental Pollution 148:107-114.

Van Nevel, L., J. Mertens, J. Staelens, A. De Schrijver, F.M.G. Tack, S. De Neve, E. Meers, and K. Verheyen. 2011. Elevated Cd and $\mathrm{Zn}$ uptake by aspen limits the phytostabilization potential compared to five other tree species. Ecological Engineering 37:1072-1080.

Vos, P.E.J., B. Maiheu, J. Vankerkom, and S. Janssen. 2013. Improving local air quality in cities: To tree or not to tree? Environmental Pollution 183:113-122.

Wang, L., S. Gao, E. Has, and Z. Wang. 2006. Physicochemical characteristics of ambient particles settling upon leaf surfaces of urban plants in Beijing. Journal of Environmental Science 18(5):921-926.

Wilschut, M., P.A.W. Theuws, and I. Duchart. 2013. Phytoremediative urban design: Transforming a derelict and polluted harbor area into a green and productive neighborhood. Environmental Pollution 183:81-88.

Wisniewski, L., and N.M. Dickinson. 2003. Toxicity of copper to Quercus robur (english oak) seedlings from a copper-rich soil. Environmental and Experimental Botany 5:99-107.

Xiao, Q., and E.G. McPherson: 2011. Rainfall interception of three trees in Oakland, California. Urban Ecosystem 54:755-769.

Yang, J., J. McBride, J. Zhou, Z. Sun. 2005. The urban forest in Beijing and its role in air pollution reduction. Urban Forestry \& Urban Greening 3:65-78.

Yang, X., Y. Feng, Z. He, and P.J. Stoffella, 2005. Molecular mechanisms of heavy metal hyperaccumulation and phytoremediation. Journal of Trace Elements in Medicine and Biology 18:339-353.

Zerbe, S., and G. Wiegleb. 2009. Renaturierung von Ökosystemen in Mitteleuropa. Springer, Spektrum, Heidelberg, Germany. $530 \mathrm{pp}$. 
Claudia Dadea

Faculty of Science and Technology

Free University of Bozen-Bolzano

Piazza Università 5, 39100

Bolzano, Italy

Alessio Russo

Laboratory of Urban and Landscape Design

School of Arts, Culture and Sports

Far Eastern Federal University, 690922

Vladivostok, Russia

Massimo Tagliavini

Faculty of Science and Technology

Free University of Bozen-Bolzano

Piazza Università 5, 39100

Bolzano, Italy

Tanja Mimmo

Faculty of Science and Technology

Free University of Bozen-Bolzano

Piazza Università 5, 39100

Bolzano, Italy

Stefan Zerbe (corresponding author)

Faculty of Science and Technology

Free University of Bozen-Bolzano

Piazza Università 5, 39100

Bolzano, Italy

stefan.zerbe@unibz.it

Résumé. Les arbres jouent un rôle important pour l'amélioration de la qualité de l'environnement des milieux urbains. L'amélioration du microclimat, l'atténuation des eaux de ruissellement, le stockage et la séquestration du carbone, la réduction du bruit, l'épuration de l'air par l'intermédiaire de l'élimination et de la fixation des polluants par les feuilles, les tiges et les racines sont des services écosystémiques générés par le verdissement urbain. De plus, la capacité de certaines espèces d'arbres à se signaler en tant que bio-indicateur ou pour l'absorption de contaminants doit être prise en compte. Voici donc une analyse mettant l'accent sur dix (10) espèces d'arbres ornementaux couramment plantées en bordure des rues urbaines en Europe centrale. Il s'agissait dévaluer leur rôle potentiel pour la bio-indication et la phytoremédiation. En raison de caractéristiques physiologiques et morphologiques et de la tolérance intrinsèque à plusieurs facteurs de stress, certaines espèces apparaissent particulièrement prometteuses à titre d'indicateur de l'état de l'environnement urbain ou aux fins de réduction de la quantité de polluants spécifiques. Il faut souligner que certaines propriétés des espèces intrinsèques (par exemple, la capacité de tolérance et/ou de bio-indication d'un contaminant spécifique) peuvent aider les urbanistes à créer un réseau de surveillance efficace dans les zones stratégiques d'une ville ou à détecter la présence d'un contaminant découlant d'un impact humain spécifique. De manière particulière, le Betula pendula et le Robinia pseudoacacia peuvent être considérées comme d'excellents sujets, peu onéreux pour la phytoremédiation. En raison de leur grande rusticité, de leur tolérance à la pollution et de leurs caractéristiques en tant qu'espèces pionnières, ces deux espèces peuvent en outre être considérées comme des indicateurs biologiques ou pour leur capacité de rétention foliaire de contaminants. Le Tilia cordata est également un bon spécimen pour la phytoremédiation en milieu urbain en raison de sa capacité de rétention foliaire pouvant fournir de précieuses informations sur les polluants atmosphériques.

Zusammenfassung. Trees play an important role for the improvement of environmental quality in urban areas. The Bäume spielen eine wichtige Rolle bei der Verbesserung der Umweltqualität in den urbanen Regionen. Die Verbesserung von Mikroklima, Ablaufwasserbewegung, Kohlenstoffspeicherung und -bindung, Lärmreduzierung, Luftreinigung durch die Entfernung und Fixierung von Kontaminationen in Blättern, Stämmen und Wurzeln sind ökologische Leistungen, die von urbanem Grün geliefert werden. Zusätzlich muss man die Kapazität von bestimmten Baumarten als Bioindikator oder zur Aufnahme von Kontaminationen berücksichtigen. Hier wird ein Rückblick präsentiert, der sich auf zehn ornamentale Baumarten fokussiert, die häufig in Zentraleuropa entlang von Straßen gepflanzt werden. Ihre potentielle Rolle bei Bioindikation und Phytomediation werden hier untersucht. Einige Arten scheinen aufgrund ihrer physiologischen und morphologischen Charakteristika und ihrer spezifischen Toleranz gegenüber einigen Stressfaktoren sehr vielversprechend als Indikator für den Zustand der urbanen Umwelt oder bei der Reduzierung von der Menge spezifischer Kontaminationen. Es muss darauf hingewiesen werden, dass die spezifischen Eigenschaften einiger Arten (z.B. Toleranz und/oder Bioindikationsfähigkeit für einen bestimmten Schadstoff) den Planern helfen können, ein effektives Überwachungsnetz in strategisch wichtigen Bereichen einer Stadt zu etablieren oder bestimmte Schadstoffe, die repräsentativ für eine spezifischen menschlichen Einfluss sind, aufzuspüren. Besonders Betula pendula und Robinia pseudoacacia werden als kostengünstige Arten für Phytomediation erachtet. Wegen ihrer hohen Anpassung, Toleranz gegenüber Schadstoffen und ihrer Charakteristika als Pioniergehölz, könnten beide Baumarten auch als Biomonitor in Betracht kommen, oder für ihre Fähigkeit, Schadstoffe auf ihren Blättern zu binden. Tilia cordata ist wegen ihrer Fähigkeit, Schadstoffe auf ihren Blättern zu binden auch geeignet für Phytomonitoring in urbanen Umgebungen, da so wertvolle Informationen über luftübertragene Schadstoffe gesammelt werden können.

Resumen. Los árboles juegan un papel importante para la mejora de la calidad ambiental en las zonas urbanas. La mejora del microclima, la mitigación de la escorrentía, el almacenamiento y secuestro de carbono, la reducción del ruido, la purificación del aire mediante la eliminación y la fijación de contaminantes en las hojas, tallos y raíces son servicios ecosistémicos proporcionados por la ecología urbana. Además, debe tenerse en cuenta la capacidad de ciertas especies arbóreas como bioindicador o para absorber contaminantes. Se presenta aquí una revisión que se centra en 10 especies de árboles ornamentales comúnmente plantadas a lo largo de las calles urbanas de Europa Central. Su papel potencial para la bioindicación y la fitorremediación fueron evaluados. Debido a las características fisiológicas y morfológicas, y a la tolerancia intrínseca a varios factores de estrés, algunas especies parecen particularmente prometedoras como indicador del estado del medio ambiente urbano o para disminuir la cantidad de contaminantes específicos. Cabe señalar que las propiedades intrínsecas de las especies (por ejemplo, la capacidad de tolerancia y / o bioindicación de un contaminante específico) pueden ayudar a los planificadores a crear una red de monitoreo eficaz en áreas estratégicas de una ciudad o a detectar contaminantes únicos representativos de un impacto humano específico. En particular, Betula pendula y Robinia pseudoacacia pueden considerarse candidatos ideales y de bajo costo para la fitorremediación. Debido a su alta resistencia, tolerancia a la contaminación y sus características como especies pioneras, ambas especies podrían ser consideradas como biomonitores, o por su capacidad de captura foliar. Tilia cordata también es adecuada para la fitorremediación en entornos urbanos debido a su capacidad de captura foliar que puede proporcionar información valiosa sobre contaminantes aerotransportados. 